\title{
Labour keeps its supporters guessing
}

[LONDON] Britain's Labour party last week revealed details of a National Endowment Fund for Science, Technology and the Arts (NESTA), which it promises to create if it wins next week's general election. It would initially be funded with capital from the National Lottery.

The new fund is one of the few firm commitments to have emerged from the party, which is widely expected to form Britain's next government, in a campaign marked more by rhetorical hand-waving about the importance of science being "at the centre of government" than by firm proposals about how this will be put into practice.

Even details of how NESTA - described as "the bank for British genius" - will operate remain sketchy. Labour officials say they hope that part of the fund's income will come from patent rights, either donated by individuals or corporations, or from research it has sponsored.

The model they use is the way in which the tail-end of the rights to the children's book Peter Pan were left by the author J. M. Barry in his will to Great Ormond Street Hospital for Sick Children. But they also admit that "we will have to see how things work out".

Such uncertainty is reflected more broadly in Labour's policy for science. A statement last week, for example, spoke of the need to encourage UK scientists working abroad to return to Britain. Indeed, Tony Blair, the Labour leader, announced that several had promised to do so if Labour wins power.

But no such individuals have been named, and several of those quoted in the party's press releases merely said that, while supporting the overall thrust of the party's policies, they are waiting to see how these are put into practice.

Labour's election strategy has caused frus-

\author{
IMAGE \\ UNAVAILABLE \\ FOR COPYRIGHT \\ REASONS
}

But is he listening? Tony Blair (left) with Sir Harry Kroto, Britain's most recent Nobel prize winner for his role in the discovery of the carbon molecule $\mathrm{C}-60$, at a parliamentary reception organized by the Royal Society of Chemistry last year. tration in the scientific community. Politically, however, it seems to have done the party little damage; an opinion poll by the Times Higher Education Supplement found that 64 per cent of university academics intended to vote for Labour next week, an increase from 57 per cent in the last election in 1992.

In contrast, 10 per cent plan to vote for the Conservatives, who form the present government under John Major, a drop from 17 per cent last time. Almost twice that number plan to vote for the smaller Liberal Democrat party, whose best hope is that it might - in the unlikely event of a close contest - hold the balance of power.

One reason for Labour's popularity in the academic community appears to be a widespread belief that a change of government will open up new opportunities, even if they have yet to be detailed. The reaction to the NESTA proposal already seems to have tapped some of this optimism.

Party officials stress that any money provided for science through the fund is not intended as a substitute for more conventional sources of support, in particular that which is distributed through the higher-education

\section{Return to Unesco beckons for Britain}

[LONDON] Britain could find itself

back in the United Nations

Educational, Scientific and

Cultural Organization

(Unesco), which it left in the

mid-1980s in protest at

mismanagement and

excessive administrative

costs, if the Labour party wins

next week's general election.

Labour party officials say

that in principle they would

like Britain to return "with the

minimum of delay". This may

not be immediately, as the

decision will depend partly on

a review of UK membership of

all UN agencies.

Indeed, there is a note of caution in the manifesto statement that it is Labour's "aim" to rejoin, after it has considered how this can be done "most effectively". It will also be necessary to decide where the membership subscription - which at current rates would be about $£ 10$ million (US $\$ 16$ million) a year - should come from.

The most likely source would be from reduced funding for bilateral aid programmes financed by the Overseas Development Administration, which Labour has promised to re-establish as an independent agency

The United States remains outside Unesco, which it also left in 1984, with opposition to the agency firmly entrenched in conservative circles. However, a substantial body of Democrats, led by a former secretary of state, Cyrus Vance, favour rejoining.

Labour officials now say that "we want to be very much part of the reform process", pointing out that education is already at the top of the party's domestic political agenda. D.D. funding councils and the research councils.

Nevertheless, the proposal was welcomed by the Committee of Vice-Chancellors and Principals because it would allow lottery funds to be used to address the problem of researchers "forced to use old equipment and work in poorly equipped laboratories".

Others say that their enthusiasm for a change in government lies in a conviction that a healthy science base requires a level of state intervention that Conservatives find difficult to accept. "I feel that a Labour government would bring a greater appreciation of the value of public institutions and of public sector activities," says Sir Martin Rees, professor of astronomy at the University of Cambridge. "There would be less of a tendency to feel that everything has to be run as a business."

The present government - in science, as more broadly - is fighting the election on its recent record, and is not totally without supporters in the scientific community. But such voices appear to be in the minority. Indeed, most observers feel that the main question now is not whether Labour will win next week's election, but what it will do once it does. And the lack of such details in the party's manifesto, has only fanned speculation.

The party has said it will not create a ministry of science. But one move that some feel it may take is to appoint key scientific figures to 'life peerages' to act as spokesmen in the House of Lords, as it is entitled to do in the traditional dissolution honours list.

Rees himself, who has been actively promoting greater public understanding of science, is seen by some as a possible candidate. Another figure widely expected to play a prominent role in a Labour administration is Sir Tom Blundell, until recently chairman of the Biotechnology and Biological Sciences Research Council.

Although Blundell - an active Labour member of the Oxford City Council in the early 1970 s - has only lately become professor of biochemistry at the University of Cambridge, there are some who are keen that he should use his experience to play a central coordinating role in whatever policy the Labour party might put into place.

DavidDickson 